\title{
THE LEGAL PROTECTION WEAKNESSES ON COSTUMERS OF ONLINE SHOP TRANSACTIONS
}

\author{
Ukie Tukinah \\ Sekolah Tinggi Ilmu Ekonomi Semarang \\ ukie.tukinah@stiesemarang.ac.id
}

\begin{abstract}
Electronic transactions that are practiced in online transactions create unequal bargaining power between businesses and customers. Business actors often use the weak position of customers to get the maximum benefit from customers. This study uses a normative juridical approach. The research results obtained include the weaknesses of law enforcement, both from the Customer Protection Agency and the Indonesian Customers Foundation, arguing that there are factors that cause customer protection conditions in Indonesia to be so alarming: First, there is still an asymmetrical relationship between producers and customers. Second, customers generally do not meet sufficient bargaining power against business actors. Third, the Government in general tends to side with business actors. Fourth, there is no sense of concern from existing law enforcement institutions, both from the Police, Attorney General's Office, and the Court.
\end{abstract}

Keywords: E-Commerce, Legal Protection, Weaknesses.

\section{A. INTRODUCTION}

The Indonesian nation has a noble legal instrument as the foundation of national and state life, namely Pancasila and the 1945 Constitution. The consequence of making Pancasila as the basis of the nation's philosophy means that in every life of the nation and state, Pancasila must be the basis that animates every step of development including the development of the Indonesian National Law System., both in the development of legal substance, legal structure and legal culture. ${ }^{1}$

Technological developments are very significant, resulting in developments in various aspects of people's lives. Including the business community, while the trading community has taken advantage of technological advances. Not only that happens in trade traffic, but also in trade relations. ${ }^{2}$ Online transactions are a new way of buying and selling by utilising advances in information technology. Online transactions develop in society as a result of technological developments and the increasing number of internet users in Indonesia. ${ }^{3}$

1 Sri Endah Wahyuningsih Urgensi Pembaharuan Hukum Pidana Materiel Indonesia Berdasarkan Nilai-Nilai Ketuhanan Yang Maha Esa, Jurnal Pembaharuan Hukum, Vol I No.1 January-April 2014, page.17-23

2 Andri Winjaya Laksana, Cybercrime Comparison Under Criminal Law In Some Countries, Jurnal Pembaharuan Hukum, Vol V No.2 April-August 2018, page.217-226

3 Rifan Adi Nugraha, Perlindungan Hukum terhadap Konsumen dalam Transaksi Online, Jurnal Serambi Hukum, Vol. 08 No. 02, August 2014-January 2015, page. 91 
Customer-only transactions on the Internet (World Wide Web) involve retail trade operators (run by individuals, families or groups, or incorporated companies) who take orders from customers and fulfill them directly from their own inventory or, if the retail operator does not own any savings, indirectly through manufacturers or wholesalers who pack and deliver goods to customers on their behalf. ${ }^{4}$ Companies use e-commerce on many levels. There are those who just use e-mail for certain parts, for example: only applied in the sales department. But there are also those who use web pages to display company and product profiles. ${ }^{5}$

In the business world, a website in the form of e-commerce is already a necessity for a business that has advanced today for business development because there are various benefits that e-commerce has. Among them are customers who do not need to come directly to the store to choose the items they want to buy and for companies to carry out transaction activities for 24 hours. Second, from a financial point of view customers can save costs and for entrepreneurs can save on promotional costs, if the location of the store is far away, customers can save on travel costs by being replaced by cheaper shipping costs and for entrepreneurs they can market their shops to a wider area. ${ }^{6}$

Along with the development of today's business world, e-commerce is a necessity to increase and win business competition and product sales. In the process of using e-commerce, buying and selling and marketing activities are more efficient where the use of e-commerce will show ease of transactions, reduce costs and speed up the transaction process. The quality of data transfer is also better than using manual processes, where there is no re-entry which allows human errors to occur. ${ }^{7}$

The development of electronic transactions is inseparable from the growth rate of the internet, because electronic transactions run through the internet network. The rapid growth of internet users is a fact that makes the internet an effective medium for businesses to introduce and sell goods or services to potential customers from all over the world. ${ }^{8}$

Electronic trading in practice is similar to traditional trading, but has advantages that can directly benefit to increase company income and profits. With its flexibility, electronic commerce can cut marketing costs with its ease and sophistication in conveying information about goods and services directly to customers wherever they are. Companies that do business electronically can also cut store operating costs because they don't

4 Assafa Endeshaw, Hukum E Commerce dan Internet dengan Fokus di Asia Pasifik, Pustaka Pelajar, Yogyakarta, 2007, page. 400.

5 Didi Achjari, Potensi Manfaat Dan Problem di E-Commerce, Jurnal Ekonomi dan Bisnis Indonesia, Vol. 15, No. 3 2000, page.388 - 395

6 Shabur Miftah Maulana, Heru Susilo, Riyadi, Implementasi E-Commerce Sebagai Media Penjualan Online (Studi Kasus Pada Toko Pastbrik Kota Malang), Jurnal Administrasi Bisnis

7 Ibid. (JAB), Vol. 29 No. 1 December 2015, page.1-9

8 Dianne Eka Rusmawati, Perlindungan Hukum Bagi Konsumen Dalam Transaksi E-Commerce, Fiat Justisia Jurnal IImu Hukum, Volume 7 No. 2, May-August 2013, page.198-201 
need to display their goods in large stores with many employees. ${ }^{9}$ Electronic transactions that are practiced in online transactions create unequal bargaining power between businesses and customers. It can be explained by the fact that business actors selling their goods and / or services online often include standard contacts so as to create asymmetric bargaining power (unequal bargaining power).

Business actors often use the weak position of customers to get the maximum benefit from customers. The factor of customer ignorance is due to unclear information on goods / services provided by business actors, customers do not understand the transaction mechanism. Therefore, in order to create a healthy business climate for customers in conducting trade transactions through e-commerce, it is necessary to seek a new and adequate form of legal regulation capable of regulating all their activities. ${ }^{10}$

The purpose of writing in this study is to determine and analyze the weaknesses of legal protection in unjust online shopping (e-commerce), due to the wide impact that can be generated. It is hoped that it can be useful theoretically for the development of legal science, especially customer protection (e-commerce) and business actors, as well as this research is expected to find new theories of law enforcement to fulfill the sense of justice in society.

\section{B. RESEARCH METHODS}

The researcher used a normative juridical research method with 3 (three) approaches to examine the two problems discussed by this normative research method, namely the legal approach and the conceptual approach. A statutory approach is needed to trace the legislative ratios and the ontological basis for the formation of legislation. ${ }^{11}$ The specification of this research is descriptive analysis, which is research that not only describes the state of the object but provides an overview of the weaknesses of legal protection in unjust e-commerce, due to the wide impact it can have. It is hoped that it can be useful theoretically for the development of legal science, in particular. customer protection (ecommerce) and business actors, as well as this research is expected to find new theories of law enforcement to fulfill the sense of justice in society. ${ }^{12}$

\section{RESULTS AND DISCUSSION}

\section{Juridical Weaknesses In Online Transactions}

The development of e-commerce is very significant, so it must be balanced with legal certainty that regulates protection for e-commerce customers. Until now, protection for e-commerce customers has not been made. This worsens the condition of customer protection due more

9 Nuryanti, Peran E-Commerce Untuk Meningkatkan Daya Saing Usaha Kecil Dan Menengah (UKM), Jurnal Ekonomi, Volume 21, Nomor 4 December 2013, page.1-15

10 Elisatris Gultom, Cyber Law: Suatu Pengatur Pelindungan Konsumen Dalam Transaksi Perdagangan Melalui Elektronic Commerce, Elips, Bandung, 2012, page. 55

11 Peter Mahmud Marzuki, Penelitian Hukum, Kencana, Jakarta, 2014, page. 93-94

12 Ronny Hanitijo Soemitro, Metode Penelitian Prosedur Dan Strategi, Sinar Pagi, Jakarta, 1985, page.9 
to the weakness of the system, seen from the weak coordination between departments or institutions, for example in the issuance of integrated regulations.

In terms of protecting customers involved in online transactions, Rothchild highlighted that the inherently international nature of electronic commerce presents an "opportunity" and a "challenge" to customer protection policies as a result of "disinter mediation". Compared to customer contracts through suppliers in the same jurisdiction, disinter mediation allows customers to directly enter into contracts with sellers (business actors) who are in other jurisdictions. This disintermediation of customer contracts provides benefits and challenges to businesses and customers. ${ }^{13}$

Customer rights as stated in Article 4 of Act No. 8 of 1999 concerning Customer Protection are broader than the basic rights of customers as first put forward by the President of the United States J.F. Kennedy before the congress on March 15, 1962, which consisted of:

a. The right to security;

b. The right to vote;

c. Right to information;

d. The right to be heard. ${ }^{14}$

The customer protection system in Indonesia still has many weaknesses. Weaknesses in this system result in many violations of the rights of customers or Indonesian society.

a. Weaknesses of the Customer Protection Act

1) The first weakness

There is a legal vacuum from e-commerce customer protection. Currently, the National Customer Protection Agency is working to implement Act No. 8 of 1999 concerning Customer Protection. However, the 20-year-old Law is considered unable to accommodate the current rapid technological developments, especially technological developments, especially the development of e-commerce, related to the protection of e-commerce customers.

2) The second weakness

This happened because the Personal Data Protection Act was not immediately promulgated into a regulation. At the same time, customer personal data is used in a number of digital applications.

If you buy goods on sites of online business actors such as Shopee, Tokopedia, Buka lapak, Lazada, Zalora, it turns out that it is not suitable or there is chemical contamination, who is responsible? When asked for data, which stores Lazada or other people, this is actually not clear in Indonesia.

13 Lorna E. Gillies, Electronic Commerce and International Private Law, A Study of Electronic Consumer Contracts, Ashgate Publishing Limited, England, 2008, page.28-29.

14 Ahmadi Miru \& Sutarman Yodo, Hukum Perlindungan Konsumen, edisi Revisi, PT. Raja Grafindo, Jakarta, 2015, page. 38 
3) The third weakness

This happens because of the many channels of complaints for the community, especially e-commerce customers. For example, the BPKN only acts as a complaint receiving agency. For the settlement process, the authorized institution is the Customer Dispute Resolution Agency.

b. Weaknesses of the Law on Electronic Information and Transactions

E-commerce has weaknesses, namely the method of electronic transactions that does not bring business actors together with customers directly, and there is no opportunity for customers to see directly the goods ordered have the potential to cause problems that harm customers, including mismatching of the type and quality of goods promised, inaccuracies time of delivery of goods, insecure transactions ranging from payments using other people's credit cards (piracy), illegal access to information systems (hacking), website destruction to data theft.

Furthermore, payment by filling in a credit card number in a public internet network also carries no small risk, because it opens up opportunities for fraud or theft.

Transaction problems through e-commerce have a large enough risk. Especially regarding the payment there is a risk of loss on the part of the customer, because the customer is usually required to make a payment in advance, while he cannot see the quality of the goods ordered and there is no guarantee of certainty that the goods ordered will be sent according to the agreement.

From a legal point of view, the problems are related to legal certainty. These problems include, for example, the validity of business transactions from the aspect of civil law (for example if it is carried out by someone who is not yet capable / mature), the problem of digital signatures or electronic signatures and data mesage. In addition to other problems that arise, for example, with regard to guaranteeing the authenticity of data, confidentiality of documents, obligations in relation to taxes, the law appointed in case of breach of agreement or contract, issues of legal jurisdiction and also which legal issues should be applied in the event of a dispute.

If you pay attention to the legal protection for customers, it is quite complete, especially from e-commerce, there are other supporting regulations, namely Law No. 11 of 2008 concerning the Law on electronic information and transactions. In fact, customers are still victims of transactions in e-commerce because business actors do not pay attention to business ethics, entrepreneurs who are not responsible for losses or delays in delivery times, as well as defective goods, these business actors take advantage of the situations and conditions of the existence of customers who are far away and not face to face with business actors. From the customer side, namely the lack of knowledge about e-commerce, there needs to be an even and continuous socialisation of the applicable rules and regulations. 
Customers must pay attention to the slogan carefully before buying. Customers themselves must also know what their rights and obligations are. ${ }^{15}$

The agreement that exists in e-commerce also applies to the principles in the Civil Code. In the Criminal Code, customer protection exists in article 378, which protects customers from fraud, including those committed by business actors. Regarding evidence of electronic transactions since the enactment of Law no. 11 of 2008, then electronic transaction files or e-commerce files can be used as evidence.

E-commerce transaction security guarantees are needed to protect customers and foster customer confidence, and in the end it is hoped that an increase in the volume of transactions through ecommerce is expected.

In relation to protection guarantees, not a few customers are unaware of the ITE Law or protection guarantees provided by other laws and regulations, including the Customer Protection Law. This is especially so for customers who are unfamiliar and inexperienced in online transactions with concerns that their transactions are not as expected. This concern is mainly for sellers or business actors who offer their goods through online shops or electronic system providers that facilitate transactions without certification.

When compared with transactions in the real world, transactions or buying and selling relations in cyberspace have the potential for crime or at least harm other parties, which is much greater, in addition to the benefits of each party. This is due to the easier interaction between business actors and customers who transcend national boundaries. Although in various countries, even internationally, various regulations have been established that attempt to eliminate actions in transactions that are detrimental to other parties, this is not fully controllable by state agents having the authority to do so. The difficulty in controlling legally is mainly due to issues of jurisdiction and legal substance that are not yet fully harmonised between one country and another, including dispute resolution mechanisms or procedures.

The gap in positions between one company and another business actor or between business actors and customers conducting transactions is not easily aligned, with the position of customers being weaker than business actors. This appears to be an inherent trait in the principle of freedom of contract. Therefore, it is not uncommon for a contract to emerge, which substantively, the whole of its intent, whether understood or not understood by the customer, puts the customer at a disadvantage. It is not an exaggeration if the Customer Protection Law sets limits for business actors. These limits can mean giving additional strength to customers so that their weak position

15 Ambar Wariati, Nani irma Susanti, E-Commerce Dalam Perspektif Perlindungan Konsumen, PRO-BANK, Jurnal Ekonomi \&Bisnis, Vol. 1. No. 2 2014, page.1-19 
can be protected from the abuse of the strong position of business actors to gain profits at the expense of customers. In the context of electronic trading, the ITE Law does not impose limits on business actors or business actors in their relationship with customers, so that it is fully based on the Customer Protection Law. The regulation of the ITE Law is general in relation to the implementation of electronic transactions and electronic systems.

The limitations regulated by the Customer Protection Law in relation to electronic contracts and matters relating to electronic contracts do not in itself guarantee the absence of potential customer losses caused by contract terms and contracts made by companies or business actors. This shows that the legal terms of the agreement in article 1320 of the Criminal Code are not yet effective because the information on contract terms is incomplete and clear where the competent element has not been regulated even though someone can make buying and selling transactions at the age of 18 years and over, the element of agreement is that there are still many customers who are disadvantaged. Because the making of standard or standard contracts in electronic commerce places customers in a weaker position compared to business actors, for certain elements customers suffer a lot because the ordered goods received by customers do not match what is offered, such as in the purchase of household appliances, there are many disappointments that experienced by customers and the elements of halal causes, many prohibited items are easily obtained through electronic trading.

Apart from customer knowledge of the provisions of the Law on Electronic Information and Transactions, actually in the Law on Electronic Information and Transactions there are several provisions that indirectly provide protection for customers. The provisions referred to include: electronic information as valid legal evidence (Article 5), digital certificate, which in Articles 13 and 14 of the Law on Electronic Information and Transactions is called "electronic certificate", the obligation to administer an electronic system in an electronic manner reliable and safe and responsible. In fact, this is difficult to enforce, so there is a possibility that electronic system operators that are not certified may emerge.

\section{Legal Protection for E-Commerce customers based on the value of justice}

Electronic commerce which continues to develop will also be followed by the development of laws that provide customer protection. This is directly proportional to the level of customer confidence and the increase in electronic transactions (e-transactions). Therefore, laws and regulations on customer protection as well as the Law on Information and Electronic Transactions are needed which can guarantee the settlement of the main problems of concern in electronic trading. As stated by Sutatip Yuthayotin in a study in the European Union that: A recent EU survey on customer confidence revealed that the confidence 
level of E-Commerce is extremely low. Approximately $56 \%$ of the surveyed e-customers gave the reason that foreign businesses are less likely to comply with customer protection law. Around $71 \%$ of the customers surveyed cite the extreme difficulty in resolving dispute, e.g., those that may arise from return of goods, price settlement, warranties, etc., as the reason for such lack of confidence. About $65 \%$ of the surveyed customers believe it would be problemetic if they change their mind and return the products that they purchased online for a merchant locating abroad. ${ }^{16}$

A recent European Union survey of customer confidence revealed that the level of confidence in e-commerce is very low. An estimated $56 \%$ of surveyed e-commerce customers argued that foreign businesses were poorly compliant with customer protection laws. Approximately $71 \%$ of the customers studied stated that it was very difficult to resolve disputes, such as returning goods, settling prices, guarantees, and so on, as reasons for their lack of trust. About $65 \%$ of customers studied believe this to be a problem when they change their intentions and return products that have been purchased online from sellers located abroad. Furthermore, it is said that:

Looking at the above data, it can be said that customers around the world have no great confidence in E-Commerce and this constitutes an important barrier that prevent customers from participating in online sales. This, as a result, undermines the potential growth of B2C etransactions. In a global debate on customer protection in the online market, a lack of customer trust in the existing customer protection standard is the main problem that needs to be addressed. ${ }^{17}$

There is a need for a new concept regarding the law of electronic commerce (e-commerce law), in particular the law that guarantees customer protection. The customer protection law and the Information and Electronic Transaction Law in this case are an instrumental form of law, which organises the achievement of the goals of a fair and efficient customer market. This means that in the customer market in cyberspace, the customer-business actor relationship does not merely give the business actor a greater weight of profit, but is balanced with meeting the needs or interests of customers. Nonetheless, neither the customer protection law nor the Electronic Information and Transaction Law does not hinder the development of electronic commerce. As a comparison, it is also a concern that UNCITRAL's Model Law on Electronic Commerce (1996) was formed, especially in relation to limitations or requirements regarding writing and electronic signatures. As Paul Todd said, "UNCITRAL appears to have feared that development of state laws, such as those in Utah, Germany and Italy, might impede the development of E-Commerce." (UNICITRAL appears to be concerned that developments

16 Sutatip Yuthayotin, Access to Justice in Transnational B2C E-Commerce, A Multidimentional Analysis of Consumer Protection Mechanisms, New York, Dordrecht, Springer International Publishing Switzerland, London, 2015, page.22-23.

17 Ibid., page. 23 . 
in state law, such as in Utah, Germany, and Italy, could hamper the development of e-commerce.)

At first customer protection law in particular, was developed from the concept of inequality of bargaining power, contemporary customer protection law is the best conceptualization as regulation of the customer market and includes an analysis of the relative role of public, private and self-regulatory techniques. A study of institutional discretion and the issue of guaranteeing the effectiveness and the formation of accountable laws, standard sets and enforcement. This regulatory perspective removes the traditional distinction between private and public law, and includes soft law, moral and other "non-legal" techniques in this area. Instrumental conceptualization undermines legal reasoning autonomy because analysis of customer protection law and policy refers to disciplines such as economics and sociology that contribute to understanding customer behaviour and the consequences of different policy choices. ${ }^{18}$

The law of electronic trading is currently experiencing a lack of uniformity (equality), an unfavorable situation since electronic trading transactions are often carried out by people from different countries. Apart from differences, the world's e-commerce laws have other drawbacks, ${ }^{19}$ so that the Law on Information and electronic transactions or the provisions regarding contracts in the Civil Code also still need harmonisation to approach the uniformity of the law. The reconstruction in this case uses a comparative law and culture approach, as expressed by Jean Brissaud, a legal historian, who has compared society with biological organisms when discussing the history of law in France. In the same way, legal systems are like living things. Legal systems have specific and separate organs, each carrying out its own function and as a whole declaring something that is alive and continues (survives). In this connection, legal reconstruction such as major surgery. ${ }^{20}$ In this surgery, organ transplants that are imported from other people's bodies can be performed. Likewise, the reconstruction of national law is related to weaknesses in dealing with electronic commerce, especially in terms of information on contract terms. This reconstruction is related to the substantive customer protection law. As stated by Lorna E. Gillies, this substantive customer protection law is to provide material justice to customers in recognition of the inequality of bargaining power between the parties. ${ }^{21}$ Furthermore, by quoting Ramsay's opinion, Gillies emphasised that the substantive customer protection law must be critical of the inequality of bargaining power as a reason for customer

18 Iain Ramsay, Consumer Law, Regulatory Capitalism and the 'New Learning' in Regulation, Sydney Law Review, Vol.28:9 2006, page.9-10.

19 Stephen Errol Blythe, The E-Commerce Law Trilogy: Volume 2, An E-Commerce Law for the World: The Model Electronic Transaction Act, Xlibris Corporation, USA, 2012, page.25.

20 Dan E. Stigall, Comparative Law and State-Building: The Organic Minimalist" Approach to Legal Reconstruction", Loyola of Los Angeles Internationalo and Comparative Law Review, Vol.1-1 (2007), page.1

21 Lorna E. Gillies, Op.Cit, page.17. 
protection. The quote referred to, namely: ......the concept for those market and private-law failure which cause customers to suffer economic detriment. It is therefore necessary in a case of alleged unequal bargaining power to diagnose its particular source, for example, information failure, or the high transaction costs of redress or of customer organization. ${ }^{22}$

In another section, Gillies emphasised that the main approaches for legal regulation of electronic trading activities are individual state regulation, model laws and harmonisation. Since the objective of substantive customer protection law is to protect customers, customers are undoubtedly given juridical protection through international private law, regardless of the methods used by the parties in one-to-another contracts. To achieve this goal, the government must adapt the rules regarding electronic trading contracts in its jurisdiction. ${ }^{23}$

\section{CONCLUSION}

Weaknesses in law enforcement, both from the Customer Protection Agency and the Indonesian Customers Foundation, argue that there are factors that cause the condition of customer protection in Indonesia to be so alarming: First, there is still an asymmetrical relationship between producers and customers. Second, customers generally do not meet sufficient bargaining power against business actors. Third, the Government in general tends to side with business actors. Fourth, there is not enough care from existing law enforcement institutions, both from the Police, the Attorney General's Office, and the Court. Weaknesses in customer protection, which indicate an imbalance in the position between business actors and customers, among others, the Law on Information and Electronic Transactions as well as the Law on Customer Protection and information on contract terms that may even lead to unbalanced standard contracts information on contract terms is difficult to access; and information on contract terms is not complete and clear. 


\section{Books:}

\section{BIBLIOGRAPHY}

Ahmadi Miru \& Sutarman Yodo, 2015, Hukum Perlindungan Konsumen, edisi Revisi, PT. Raja Grafindo, Jakarta;

Assafa Endeshaw, 2007, Hukum E-Commerce dan Internet dengan Fokus di Asia Pasifik, Pustaka Pelajar, Yogyakarta, 2007;

Elisatris Gultom, 2012, Cyber Law: Suatu Pengatur Pelindungan Konsumen Dalam Transaksi Perdagangan Melalui Elektronic Commerce, Elips, Bandung;

Lorna E. Gillies, 2008, Electronic Commerce and International Private Law, A Study of Electronic Customer Contracts, Ashgate Publishing Limited, England;

Paul Todd, 2007, E-Commerce Law, London, Sydney, Portland, Oregon, Cavendish Publishing Limited;

Peter Mahmud Marzuki, 2014, Penelitian Hukum, Kencana, Jakarta;

Ronny Hanitijo Soemitro, 1985, Metode Penelitian Prosedur Dan Strategi, Sinar Pagi, Jakarta;

Stephen Errol Blythe, 2012, The E-Commerce Law Trilogy: Volume 2, An ECommerce Law for the World: The Model Electronic Transaction Act, Xlibris Corporation, USA;

Sutatip Yuthayotin, 2015, Access to Justice in Transnational B2C E-Commerce, A Multidimentional Analysis of Customer Protection Mechanisms, New York, Dordrecht, Springer International Publishing Switzerland, London;

\section{Journals:}

Ambar Wariati, Nani irma Susanti, E-Commerce Dalam Perspektif Perlindungan Konsumen, PRO-BANK, Jurnal Ekonomi \& Bisnis, Vol. 1. No. 2 2014;

Andri Winjaya Laksana, Cybercrime Comparison Under Criminal Law In Some Countries, Jurnal Pembaharuan Hukum, Vol V No.2 April-August 2018;

Dan E. Stigall, Comparative Law and State-Building: The Organic Minimalist" Approach to Legal Reconstruction", Loyola of Los Angeles Internationalo and Comparative Law Review, Vol.1-1 (2007);

Dianne Eka Rusmawati, Perlindungan Hukum Bagi Konsumen Dalam Transaksi E-Commerce, Fiat Justisia Jurnal IImu Hukum, Volume 7 No. 2, May-August 2013;

Didi Achjari, Potensi Manfaat Dan Problem di E-Commerce, Jurnal Ekonomi dan Bisnis Indonesia, Vol. 15, No. 3 2000;

Iain Ramsay, Customer Law, Regulatory Capitalism and the 'New Learning' in Regulation, Sydney Law Review, Vol.28:9 2006; 
Nuryanti, Peran E-Commerce Untuk Meningkatkan Daya Saing Usaha Kecil Dan Menengah (UKM), Jurnal Ekonomi, Volume 21, No 4 December 2013;

Rifan Adi Nugraha, Perlindungan Hukum terhadap Konsumen dalam Transaksi Online, Jurnal Serambi Hukum, Vol. 08 No. 02, August 2014January 2015;

Shabur Miftah Maulana, Heru Susilo, Riyadi, Implementasi E-Commerce Sebagai Media Penjualan Online (Studi Kasus Pada Toko Pastbrik Kota Malang), Jurnal Administrasi Bisnis (JAB), Vol. 29 No. 1 December 2015;

Sri Endah Wahyuningsih Urgensi Pembaharuan Hukum Pidana Materiel Indonesia Berdasarkan Nilai-Nilai Ketuhanan Yang Maha Esa, Jurnal Pembaharuan Hukum, Vol I No.1 January-April 2014; 